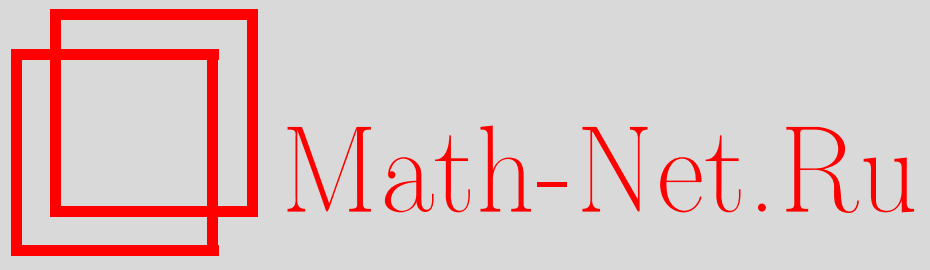

Олег Викторович Висков (02.02.1937 - 21.06.2018), Теория вероятн. и ее примен., 2018, том 63, выпуск 4, 827

DOI: https://doi.org/10.4213/tvp5258

Использование Общероссийского математического портала Math-Net.Ru подразумевает, что вы прочитали и согласны с пользовательским соглашением http://www.mathnet.ru/rus/agreement

Параметры загрузки:

IP: 3.85 .73 .92

26 апреля 2023 г., $14: 37: 23$

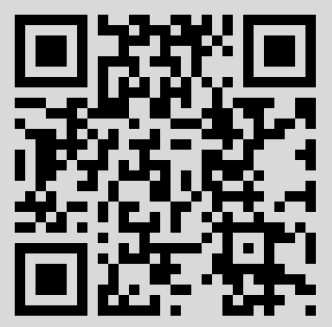




\section{ОЛЕГ ВИКТОРОВИЧ ВИСКОВ (02.02.1937 - 21.06.2018)}

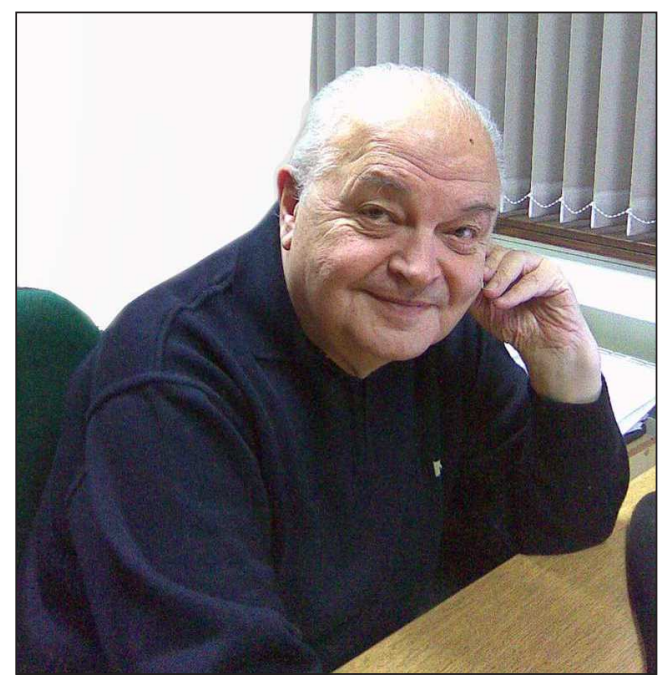

21 июня 2018 года после тяжелой болезни скончался старший научный сотрудник отдела теории вероятностей и математической статистики Математического института им. В. А. Стеклова Российской академии наук Олег Викторович Висков.

Олег Викторович внес значительный вклад в развитие асимптотических методов теории массового обслуживания и теории надежности. Ему принадлежит одна из первых в мировой литературе публикаций, стимулировавшая изучение важного класса случайных процессов, получивших позднее наименование полумарковских процессов. Специфические прикладные задачи перечисления объектов над конечными полями привели к созданию новой комбинаторной техники, базирующейся на использовании некоммутативной алгебры. Разработанные в этом направлении методы позволили показать, что имеющая широкие применения теория биномиального перечисления является частным проявлением специфических свойств алгебры Гейзенберга-Вейля. С использованием этих связей были получены также новые существенные результаты в различных областях классического анализа, теории вероятностей, алгебры, теории дифференциальных уравнений, теории специальных функций.

Олег Викторович много лет читал курс теории вероятностей в Московском физико-техническом институте, внеся весомый вклад в подготовку научных кадров высшей квалификации.

Олег Викторович был хорошим товарищем и приятным собеседником, замечательным любителем музыки. Светлая память о нем навсегда сохранится в наших сердцах. 